\title{
Embryo donation among Latin-Americans who have attended assisted reproduction techniques: a first empirical approach
}

\author{
Jorge Alberto Álvarez-Díaz ${ }^{1}$ \\ ${ }^{1}$ Departamento de Atención a la Salud. Universidad Autónoma Metropolitana. Unidad Xochimilco, México
}

\begin{abstract}
Objective: To determine whether Latin Americans who have undergone assisted reproduction techniques would donate embryos.

Methods: This is a multinational cross-sectional study, involving 602 patients. We invited the Latin American Network of Assisted Reproduction centers. Those who accepted received the instrument distributed among the patients who agreed by signing the informed consent form. In total, 261 men and 341 women participated from seven countries.

Results: Patients would donate their embryos as follows: treatment with embryonic stem cells (73.6\%), heterosexual couples (63.8\%), Assisted Reproduction Techniques (ART) research (57\%), scientific or basic research $(55.3 \%)$, research with embryonic stem cells $(55.2 \%)$, premenopausal women $(53.8 \%)$, single women $(45.1 \%)$, people with disabilities $(25.4 \%)$, lesbians $(25.3 \%)$, menopausal women $(25.2 \%)$, lesbian couples $(24.6 \%)$, gay couples $(19.6 \%)$, senile women $(15.1 \%)$.

Conclusions: The results favor embryos donation for research purposes, and a little less for clinical purposes, contrary to what was thought in qualitative studies conducted among Latin American populations.
\end{abstract}

Keywords: embryo transfer, embryo destination, embryo research, reproductive techniques, bioethics

\section{INTRODUCTION}

The first in vitro fertilization occurred in a physiological cycle. Techno-scientific approaches hyperstimulated the ovary so that it produced more than one oocyte, thus increasing the odds of achieving fertilization and implantation, and eventually a live newborn. Therefore, new medical possibilities and bioethical issues emerged: oocyte donation, embryo donation, and the possibility of transferring embryos to a different woman than the one who produced the gamete (surrogacy).

We estimate the need for approximately fifteen oocytes to achieve a live birth (Sunkara et al., 2011). While obstetric history must be considered clinically (Goldberg et al., 2016); the current trend is the transfer of a single embryo. The development of vitrification as a cryobiology technique for the preservation of embryos in a blastocyst reduced the number of oocytes captured and the number of embryos generated (Liebermann, 2017).

When the "leftover embryos" appeared, they were given several names that do not necessarily express the same meaning: remnants, supernumeraries, surpluses, leftovers, spare, unused, unwanted, renounced, unclaimed and abandoned. Alternatively, the term "embryo donation" became "embryo adoption", common in the Christian tradition (Robertson, 2018). According to the American
Society for Reproductive Medicine (ASRM), its use is inaccurate and not recommended (Ethics Committee of the ASRM, 2016a). In this study, we used the most accurate concepts of "remaining embryos" and "embryo donation" (ED). The Latin American Registry of Assisted Reproduction (RLA) of the Latin American Network of Assisted Reproduction (REDLARA) only includes the number of embryonic transfers and embryo transfers originated through oocyte donation, but it does not have data on ED, so that it is challenging to have quantitative approximations of the phenomenon among Latin Americans (Zegers-Hochschild et al., 2019).

ED has reproductive and non-reproductive indications (Dayal, 2013). Among the first are couples with poor prognosis indicators to achieve pregnancy (ovarian failure, tubal factor, uterine factor, male factor, carriers of genetic diseases, cancer survivors, failure in previous attempts with assisted reproduction techniques (ART), and the like). Among the latter, the economic factor prevailed, since if women only go for embryo transfer, the costs decrease by at least half; ED is approximately twice as profitable as donating oocytes, concerning cost per live birth (Finger et al., 2010), and even cheaper than adopting a child (Gilman \& Freivalds, 1997). ED also provides single women and lesbian couples with an additional opportunity to have children of their own (Marina et al., 2010). Another non-reproductive indication has been research.

Theoretically, there are three possible destinations for remaining fresh embryos: cryopreserve, discard and donate. Three possible destinations are also available for the remaining cryopreserved embryos: remaining cryopreserved for own use, discarded and donated. Therefore, at least two moments are at hand to decide the fate of the remaining embryos: fresh and cryopreserved. Finally, couples donate their embryos for the following possible purposes: clinical use (or reproductive use, own use, or for someone else), research, and education. ED for education (training of clinical embryologists) is a proposal, even in developed countries.

Research with human embryos generated a growing literature on embryonic stem cells. In 1998, a group from the University of Wisconsin isolated cells from the internal embryonic cell mass and developed the first embryonic stem cell lines (Thomson et al., 1998). In Latin America, the first line of human embryonic stem cells came from Colombia in 2006 (Lucena et al., 2006). Although research on induced pluripotent stem cells has grown, generating them does not solve the problem of remaining cryopreserved embryos, since they were generated in parallel during the process of assisted reproduction.

This study aimed to investigate the opinions for ED in a sample of infertile Latin American patients in order to obtain information that could be useful for reproductive medicine centers and the design of ED standards, regulations, or policies (both ethical and legal), without violating the preferences of couples. 


\section{MATERIALS AND METHODS}

We contacted and invited REDLARA accredited centers. Those who responded received complete information about the study (project and instrument). Some members of the reproductive medicine center team made the personal invitation to participate and carried out the informed consent process. If patients agreed to participate in the investigation, they would answer the questionnaire themselves, and after doing so, they could withdraw their consent, not submitting the completed questionnaire. The questionnaire was anonymous in order to preserve confidentiality.

This is a cross-sectional, observational, and descriptive study. We created an ad hoc instrument, consisting of questions used in previous similar surveys found in the background of this study and relevant for the study, and many other questions were explicitly created. The first part investigates personal and sociodemographic background. The second part explores religious beliefs and practices. The third part includes very brief information on their knowledge about medical history. The fourth part consisted of opinions towards ED, divided into four subgroups: the feeling of parenthood, ED for clinical purposes, ED for research purposes, and the importance of genetic linkage. We used a Likert scale to respond to the statements contained in the fourth part, where 1 represents "totally agree", 2 "moderately agree", 3 "neither agree nor disagree", 4 "moderately disagree" and 5 "totally disagree". The questionnaire had two versions (women and men). For Brazil, we used a certified translation reviewed by assisted reproduction professionals. The questionnaire also had information about the study and contact details of the principal investigator.

The inclusion criteria included: being Latin American by birth, living in a Latin American country, having already lived at least one cycle with any ART (with or without pregnancy), and agreeing to sign the informed consent form. There were no exclusion criteria. The elimination criteria were: being Latin American by birth but living outside the Latin American region, not being Latin American by birth but living in Latin America, and submitting an incomplete questionnaire.

The survey registration, statistical processing, and analysis were performed with SPSS version 16 . The study was approved first at the Complutense University of $\mathrm{Ma}$ drid, then by the REDLARA Bioethics Interest Group, and finally at each center that agreed to participate. We considered ethical aspects of the Helsinki Declaration and the CIOMS Guidelines, because of the international nature of this study.

\section{RESULTS}

In total, 702 patients agreed to participate as research subjects, agreeing to answer the questionnaire. Once completed, 18 refused to submit it, and 25 of the remaining ones were eliminated because the respondents were Latin Americans living in a developed country, 12 were not Latin Americans (in "reproductive tourism" or "cross-border reproductive care"), and 45 did not respond the questionnaire completely. Thus, we arrived at 602 research subjects (261 men and 341 women), from 15 reproductive medicine centers in 9 cities (Quito, Salto, La Paz, Lima, Bogotá, Caracas, Valencia, Ribeirão Preto, and São Paulo) and seven countries (Ecuador, Uruguay, Bolivia, Peru, Colombia, Venezuela, and Brazil).

Table 1 below summarizes the most relevant sociodemographic characteristics of the respondents (Table 1 ). Their mean age was 37.4 years, with a standard deviation of $5.7 ; 92 \%$ were legally married; $67.8 \%$ had no children; $34.9 \%$ had a bachelor's degree, and $25.1 \%$ had postgraduate education; $89 \%$ identified themselves as part of a religion; of those who felt part of a religion, $81.7 \%$ assumed to belong to the Catholic Church. Only $31.7 \%$ of the participants responded that they had cryopreserved embryos. The mean response cycle was 2.2 , with a standard deviation of 1.4 .

We assessed their feeling of parenthood, that is, the moment in which the participants identified themselves as mothers or fathers. This point provides data on how they understood the status of the embryo. Qualitative data published before this research showed that infertile couples do not have the same considerations about embryo status. They frequently refer to embryos as "children", even when they are cryopreserved. On the other hand, particularly when they have had negative experiences (no implantation and therefore no pregnancy; spontaneous abortion, and the like), the patients were identified as fathers or mothers at very different times of the assisted reproduction cycle: fertilization (in some centers, biologists comment on how many oocytes were recovered and how many of them were fertilized, and there are even those who allow parents to observe them under the microscope), embryo transfer, with positive pregnancy test, ending the first trimester of pregnancy (in some countries, even fertile women wait for this period to announce the pregnancy to family and friends), until they could see abdominal growth, and those who identified themselves as father or mother later mentioned the birth. No one referred to it after birth. More than half $(60.1 \%)$ of the research subjects were considered as parents when they received a positive pregnancy test (Table 2).

The next section of the instrument analyzes the opinions on ED for clinical purposes (Table 3). The distribution of participants donating their embryos was as follows: $63.8 \%$ to heterosexual couples; $53.8 \%$ to premenopausal women; $45.1 \%$ to single women; $25.4 \%$ to people with disabilities, $25.3 \%$ to lesbians; $25.2 \%$ to menopausal women; $24.6 \%$ to lesbian couples; $19.6 \%$ to gay couples, and $15.1 \%$ to older women.

The next section of the instrument analyzes the opinions on ED for research purposes (Table 4). Participants would donate embryos as follows: $73.6 \%$ for stem cell treatments; $57 \%$ for ART research; $55.3 \%$ for general scientific research; $55.2 \%$ for general scientific research; $55.2 \%$ for stem cell research; and $55.1 \%$ for research that is supervised to ensure it is carried out for the purposes for which they consented.

\section{DISCUSSION}

The issue of embryo status has generated heated debates. Much has been said that it could be related to religiosity, citing the "Artavia Murillo y otros. (In vitro fertilization) vs. Costa Rica" case of the Inter-American Court of Human Rights. The only confessional Central American country, Costa Rica, banned ARTs. The Court considered that it had violated the human rights of those who sued the Costa Rican state so that it was requested to pay for damages (Inter-American Court of Human Rights, 2012). The ruling is also cited in the Province of Buenos Aires, where they recognize "every human being from the moment of conception" as a "child" (Cámara Nacional de Apelaciones en lo Civil, 1999). Argentinian law used the term "dación de embriones" (from "given embryo"). However, it is not a purely Latin American issue. In France, one speaks of "I'accueil d'embryon", which can be translated as "embryo reception". However, the term "accueil" also means "welcoming", and they do not use the term "donner" (meaning "donate"; there are no references to the term "don d'embryon", which would be the translation to "embryo donation"). This has been interpreted as an "ultra-early form of adoption" (Malzac, 2011). Besides the ASRM, the 


\begin{tabular}{|c|c|c|c|}
\hline \multicolumn{2}{|l|}{ Sociodemographic data. } & \multirow[b]{2}{*}{$\begin{array}{c}\text { Men } \\
4 \\
246 \\
4 \\
1 \\
6\end{array}$} & \multirow[b]{2}{*}{$\begin{array}{c}\text { Women } \\
17 \\
308 \\
5 \\
1 \\
10\end{array}$} \\
\hline Marital status & $\begin{array}{l}\text { Single } \\
\text { Married } \\
\text { Divorced } \\
\text { Widower } \\
\text { Other }\end{array}$ & & \\
\hline Having children & $\begin{array}{l}\text { No } \\
\text { Yes, from previous couple } \\
\text { Yes, of current couple } \\
\text { Yes adopted } \\
\text { Yes, with previous partner and current partner }\end{array}$ & $\begin{array}{c}167 \\
42 \\
47 \\
4 \\
1\end{array}$ & $\begin{array}{c}241 \\
23 \\
70 \\
5 \\
2\end{array}$ \\
\hline Scholarship & $\begin{array}{l}\text { Undergraduate } \\
\text { Bachelor or equivalent } \\
\text { Master or equivalent } \\
\text { Doctorate or equivalent } \\
\text { Unspecified Postgraduate } \\
\text { Postdoctoral }\end{array}$ & $\begin{array}{c}111 \\
88 \\
6 \\
4 \\
50 \\
2\end{array}$ & $\begin{array}{c}130 \\
122 \\
19 \\
2 \\
68 \\
0\end{array}$ \\
\hline Country & $\begin{array}{l}\text { Ecuador } \\
\text { Uruguay } \\
\text { Bolivia } \\
\text { Peru } \\
\text { Colombia } \\
\text { Venezuela } \\
\text { Brazil }\end{array}$ & $\begin{array}{c}3 \\
7 \\
9 \\
12 \\
15 \\
80 \\
135\end{array}$ & $\begin{array}{c}4 \\
7 \\
11 \\
27 \\
38 \\
102 \\
152 \\
\end{array}$ \\
\hline Religion & $\begin{array}{l}\text { Any } \\
\text { Catholic Christian } \\
\text { Non-Catholic Christian } \\
\text { Buddhist } \\
\text { Bean } \\
\text { Muslim } \\
\text { Masonry } \\
\text { Santeria } \\
\text { Theist without religion ascription } \\
\text { Spiritism }\end{array}$ & $\begin{array}{c}32 \\
178 \\
29 \\
1 \\
3 \\
1 \\
1 \\
1 \\
1 \\
14\end{array}$ & $\begin{array}{c}27 \\
255 \\
37 \\
0 \\
1 \\
0 \\
0 \\
0 \\
0 \\
21\end{array}$ \\
\hline Known fertility problems & $\begin{array}{l}\text { Male factors } \\
\text { Female factors } \\
\text { Combined factors }\end{array}$ & $\begin{array}{c}97 \\
102 \\
62\end{array}$ & $\begin{array}{c}116 \\
135 \\
90\end{array}$ \\
\hline TRA & $\begin{array}{l}\text { IVF } \\
\text { ICSI } \\
\text { IVF \& ICSI } \\
\text { IVF with egg donation } \\
\text { FIV with egg donation } \\
\text { IMSI }\end{array}$ & $\begin{array}{c}112 \\
119 \\
15 \\
1 \\
0 \\
14\end{array}$ & $\begin{array}{c}144 \\
143 \\
36 \\
4 \\
1 \\
13\end{array}$ \\
\hline Transfer procedures & $\begin{array}{l}1 \\
2 \\
3 \\
4 \\
5 \\
6 \\
7 \\
8\end{array}$ & $\begin{array}{c}103 \\
79 \\
42 \\
23 \\
7 \\
5 \\
1 \\
1 \\
\end{array}$ & $\begin{array}{c}129 \\
91 \\
70 \\
30 \\
8 \\
8 \\
2 \\
3 \\
\end{array}$ \\
\hline Cryopreserved embryos & $\begin{array}{l}\text { Yes } \\
\text { No }\end{array}$ & $\begin{array}{c}83 \\
178\end{array}$ & $\begin{array}{l}108 \\
233\end{array}$ \\
\hline
\end{tabular}

European Society for Human Reproduction and Embryology (ESHRE) also uses and recommends the term "embryo donation" instead of "embryo adoption" (ESHRE Task Force on Ethics and Law, 2002).

Despite these and other arguments, the empirical data is inconclusive. Some studies show an association between religiosity and the possibility of donating embryos (MohlerKuo et al., 2009), unlike some other studies (Bangsbøll et al., 2004). There was no statistical association between ED and religiosity in this study. One possible explanation may be the "popular use of religion" (Rostas \& Droogers, 1993). According to these analyses, religious people express the official position of the Church (mainly Catholic, which does not officially accept ART; Vatican, 1995), but reinterpreted with their personal experiences, so they may feel that "God is in the laboratory" (Roberts, 2006).

The Latin American constant in legal regulation on the subject is the void. However, it does not also mean that 


\begin{tabular}{|c|c|c|c|}
\hline \multicolumn{2}{|l|}{ Feeling of parenthood } & \multirow[b]{2}{*}{$\begin{array}{c}\text { Men } \\
55 \\
37 \\
63 \\
75 \\
31\end{array}$} & \multirow[b]{2}{*}{$\begin{array}{c}\text { Women } \\
66 \\
52 \\
65 \\
122 \\
36\end{array}$} \\
\hline From fertilization & $\begin{array}{l}\text { I don't know; does not apply } \\
\text { Totally agree } \\
\text { In agreement } \\
\text { In disagreement } \\
\text { Strongly disagree }\end{array}$ & & \\
\hline From embryo transfer & $\begin{array}{l}\text { I don't know; does not apply } \\
\text { Totally agree } \\
\text { In agreement } \\
\text { In disagreement } \\
\text { Strongly disagree }\end{array}$ & $\begin{array}{l}47 \\
63 \\
86 \\
47 \\
18\end{array}$ & $\begin{array}{c}62 \\
93 \\
114 \\
54 \\
18\end{array}$ \\
\hline From the positive pregnancy test & $\begin{array}{l}\text { I don't know; does not apply } \\
\text { Totally agree } \\
\text { In agreement } \\
\text { In disagreement } \\
\text { Strongly disagree }\end{array}$ & $\begin{array}{l}85 \\
93 \\
58 \\
13 \\
12 \\
\end{array}$ & $\begin{array}{c}108 \\
157 \\
54 \\
15 \\
7 \\
\end{array}$ \\
\hline From the end of the first trimester of pregnancy & $\begin{array}{l}\text { I don't know; does not apply } \\
\text { Totally agree } \\
\text { In agreement } \\
\text { In disagreement } \\
\text { Strongly disagree }\end{array}$ & $\begin{array}{c}103 \\
69 \\
45 \\
25 \\
19\end{array}$ & $\begin{array}{c}130 \\
113 \\
45 \\
30 \\
23\end{array}$ \\
\hline From the beginning of abdominal growth & $\begin{array}{l}\text { I don't know; does not apply } \\
\text { Totally agree } \\
\text { In agreement } \\
\text { In disagreement } \\
\text { Strongly disagree }\end{array}$ & $\begin{array}{l}111 \\
75 \\
37 \\
21 \\
17\end{array}$ & $\begin{array}{c}135 \\
112 \\
46 \\
28 \\
20\end{array}$ \\
\hline From birth & $\begin{array}{l}\text { I don't know; does not apply } \\
\text { Totally agree } \\
\text { In agreement } \\
\text { In disagreement } \\
\text { Strongly disagree }\end{array}$ & $\begin{array}{c}106 \\
106 \\
18 \\
18 \\
13\end{array}$ & $\begin{array}{c}144 \\
129 \\
23 \\
23 \\
22\end{array}$ \\
\hline
\end{tabular}

people would not agree to any kind of legal regulation in place. An example is Sweden, where embryos can be cryopreserved for five years and, if not claimed, discarded. While ED is not allowed, research shows that both reproductive medicine professionals (Wånggren et al., 2014) and the general population (Wånggren et al., 2013a; b) would agree with ED. Another example is Germany, where it is forbidden to generate remaining embryos, donate them, and do research with them; however, while patients, geneticists and gynecologists would approve these practices, ethicists would not (Krones et al., 2006).

Opinions about ED for clinical or reproductive purposes show that between one-fifth and two-thirds are in favor of donating to the different contexts raised in the instrument. Data in developed countries show that up to $75 \%$ agree to donate for reproductive purposes (Wånggren et al., 2013a; b). One possible explanation is that respondents have their own experiences, knowledge, and understanding of various ART possibilities and are more positive about ED, to help other infertile couples in their effort to have children (the same project the participants of this research have or had). Some of the respondents in this study have been successful with the help of ART, while others have not, and perhaps this positively affects the response rate, acceptance, and altruistic motive. Some research has shown that the desire to help others could be significant in ED (McMahon et al., 2003). It is also notable that those who donate embryos or those who receive them do not see the procedure as similar to adoption (Millbank et al., 2017).

The least favored option in this investigation was ED to older women, where the women pregnancy age limit is a controversial issue. The ARTs allowed postmenopausal women to take on a pregnancy (with oocyte or embryo donation plus hormonal support). However, the possibility of obstetric complications increases with advanced maternal age, so that health, in general, and cardiovascular health, in particular, should be carefully evaluated (MacArthur et al., 2016). The ASRM recommends deterring women over 55 years of age seeking pregnancy, due to possible complications (Ethics Committee of the ASRM, 2016b).

On the other hand, between a fifth and a quarter of the participants would donate embryos to gay and lesbian couples. This research shows that if the ED is for single women, almost half of the respondents would donate embryos, but it falls to half (a quarter) if the recipients are lesbian. Respondents must consider the possibility of donating embryos for non-heterosexual people, even if in a low proportion. The LGBT community is another face of ARTs. The ASRM considers that it is unethical to prevent access to infertility treatments for single, gay, or lesbian people (Ethics Committee of ASRM, 2013). ESHRE extends it to gay and lesbian couples and transgender people (De Wert et al., 2014). This data show that some Latin Americans share liberal and non-discriminatory opinions, such as those of ASRM and ESHRE. ARTs have increased the classic anthropological discussions about kinship: family, father, mother, and the like are concepts that have historical and sociocultural constructions (Álvarez-Díaz, 2014). There are some recent Latin American studies, which analyze the outcome of children raised by LGTBI parents. It would be useful to educate patients about this issue, diminish fears and promote understanding (Zegers \& Salas, 2014).

Among the most favored options are those associated with research purposes, especially ED, to achieve stem cell 


\begin{tabular}{|c|c|c|c|}
\hline \multicolumn{2}{|c|}{ Embryo donation for clinical purposes } & \multirow{2}{*}{$\begin{array}{c}\text { Men } \\
42 \\
57 \\
109 \\
31 \\
22\end{array}$} & \multirow[b]{2}{*}{$\begin{array}{c}\text { Women } \\
51 \\
73 \\
145 \\
41 \\
31\end{array}$} \\
\hline Heterosexual couple & $\begin{array}{l}\text { I don't know; does not apply } \\
\text { Totally agree } \\
\text { In agreement } \\
\text { In disagreement } \\
\text { Strongly disagree }\end{array}$ & & \\
\hline Single woman & $\begin{array}{l}\text { I don't know; does not apply } \\
\text { Totally agree } \\
\text { In agreement } \\
\text { In disagreement } \\
\text { Strongly disagree }\end{array}$ & $\begin{array}{l}49 \\
34 \\
78 \\
67 \\
33\end{array}$ & $\begin{array}{c}54 \\
50 \\
109 \\
81 \\
47\end{array}$ \\
\hline Lesbian woman & $\begin{array}{l}\text { I don't know; does not apply } \\
\text { Totally agree } \\
\text { In agreement } \\
\text { In disagreement } \\
\text { Strongly disagree }\end{array}$ & $\begin{array}{l}42 \\
16 \\
52 \\
78 \\
73\end{array}$ & $\begin{array}{l}60 \\
20 \\
64 \\
98 \\
99\end{array}$ \\
\hline Woman in pre-menopause & $\begin{array}{l}\text { I don't know; does not apply } \\
\text { Totally agree } \\
\text { In agreement } \\
\text { In disagreement } \\
\text { Strongly disagree }\end{array}$ & $\begin{array}{l}48 \\
35 \\
99 \\
46 \\
33\end{array}$ & $\begin{array}{c}55 \\
50 \\
140 \\
57 \\
39\end{array}$ \\
\hline Woman in the climacteric & $\begin{array}{l}\text { I don't know; does not apply } \\
\text { Totally agree } \\
\text { In agreement } \\
\text { In disagreement } \\
\text { Strongly disagree }\end{array}$ & $\begin{array}{l}71 \\
27 \\
50 \\
82 \\
31\end{array}$ & $\begin{array}{c}92 \\
22 \\
53 \\
127 \\
47\end{array}$ \\
\hline Woman in post-menopause & $\begin{array}{l}\text { I don't know; does not apply } \\
\text { Totally agree } \\
\text { In agreement } \\
\text { In disagreement } \\
\text { Strongly disagree }\end{array}$ & $\begin{array}{l}56 \\
22 \\
31 \\
87 \\
65\end{array}$ & $\begin{array}{c}82 \\
14 \\
24 \\
121 \\
100\end{array}$ \\
\hline People with disabilities & $\begin{array}{l}\text { I don't know; does not apply } \\
\text { Totally agree } \\
\text { In agreement } \\
\text { In disagreement } \\
\text { Strongly disagree }\end{array}$ & $\begin{array}{l}79 \\
22 \\
52 \\
64 \\
44\end{array}$ & $\begin{array}{c}108 \\
20 \\
59 \\
95 \\
59\end{array}$ \\
\hline Lesbian couple & $\begin{array}{l}\text { I don't know; does not apply } \\
\text { Totally agree } \\
\text { In agreement } \\
\text { In disagreement } \\
\text { Strongly disagree }\end{array}$ & $\begin{array}{l}39 \\
15 \\
48 \\
79 \\
80\end{array}$ & $\begin{array}{c}48 \\
18 \\
67 \\
109 \\
99\end{array}$ \\
\hline Gay couple & $\begin{array}{l}\text { I don't know; does not apply } \\
\text { Totally agree } \\
\text { In agreement } \\
\text { In disagreement } \\
\text { Strongly disagree }\end{array}$ & $\begin{array}{c}35 \\
11 \\
33 \\
75 \\
107\end{array}$ & $\begin{array}{c}42 \\
13 \\
61 \\
113 \\
112\end{array}$ \\
\hline
\end{tabular}

treatments. A systematic review shows that donating embryos specifically for research ranges from $7 \%$ in France to $73 \%$ in Switzerland (Samorinha et al., 2014). Those who wish to donate embryos usually describe that decision as better than discarding them; also, they feel reciprocity towards science and medicine, since they see themselves as recipients of their benefits by having been able to go to an ART. The review shows that the most important reasons not to donate were the perception of the risks, conceptualizing the embryo as a person, and lack of information about the research projects. In this investigation, if the participants knew the project and had a way to verify it, their response was very favorable. If we are looking to build public policies and not merely state policies, we must consult the opinions and suggestions of citizens, where potential donors and reproductive medicine professionals stand out (Samorinha \& Silva, 2016).
The investigation had some limitations. One inherent to reproductive medicine services in Latin America, because most centers are private, introducing sociodemographic biases in the sample (economic and educational). Some other particular limitations are related to areas not included in the instrument used: age of receiving men, trans people, whether the donation should be anonymous or open, and the like. The ASRM suggests that the offspring should be informed about their origin (Ethics Committee of the ASRM, 2018). Advice to donors, recipients, their families, and the offspring is a crucial issue (Goedeke et al., 2016). The data shows that reproductive medicine professionals can instruct their patients well on the process of a common ART, but little information is managed regarding the issue of ED (Deniz et al., 2016). 


\begin{tabular}{|c|c|c|c|}
\hline \multicolumn{2}{|l|}{ Embryo donation for research purposes } & \multirow[b]{2}{*}{$\begin{array}{c}\text { Men } \\
46 \\
59 \\
83 \\
50 \\
23 \\
47\end{array}$} & \multirow[b]{2}{*}{$\begin{array}{c}\text { Women } \\
49 \\
74 \\
117 \\
72 \\
29 \\
54\end{array}$} \\
\hline For scientific research in general (basic science) & $\begin{array}{l}\text { I don't know; does not apply } \\
\text { Totally agree } \\
\text { In agreement } \\
\text { In disagreement } \\
\text { Strongly disagree } \\
\text { I don't know; does not apply }\end{array}$ & & \\
\hline For research with personal verification & $\begin{array}{l}\text { Totally agree } \\
\text { In agreement } \\
\text { In disagreement } \\
\text { Strongly disagree }\end{array}$ & $\begin{array}{l}45 \\
94 \\
53 \\
22\end{array}$ & $\begin{array}{c}59 \\
134 \\
71 \\
23\end{array}$ \\
\hline For research in reproductive medicine & $\begin{array}{l}\text { I don't know; does not apply } \\
\text { Totally agree } \\
\text { In agreement } \\
\text { In disagreement } \\
\text { Strongly disagree }\end{array}$ & $\begin{array}{c}43 \\
43 \\
100 \\
53 \\
22 \\
\end{array}$ & $\begin{array}{c}43 \\
58 \\
142 \\
79 \\
19 \\
\end{array}$ \\
\hline Stem cell research & $\begin{array}{l}\text { I don't know; does not apply } \\
\text { Totally agree } \\
\text { In agreement } \\
\text { In disagreement } \\
\text { Strongly disagree }\end{array}$ & $\begin{array}{l}53 \\
36 \\
97 \\
52 \\
23\end{array}$ & $\begin{array}{c}50 \\
45 \\
154 \\
73 \\
19\end{array}$ \\
\hline Stem cell treatment & $\begin{array}{l}\text { I don't know; does not apply } \\
\text { Totally agree } \\
\text { In agreement } \\
\text { In disagreement } \\
\text { Strongly disagree }\end{array}$ & $\begin{array}{c}47 \\
64 \\
118 \\
21 \\
11\end{array}$ & $\begin{array}{c}41 \\
96 \\
165 \\
28 \\
11\end{array}$ \\
\hline
\end{tabular}

On the other hand, Latin American countries that consider regulation should have a general legal framework on ARTs, and something specific that considers ED in particular. From a purely biomedical perspective, ED is a simple procedure (it involves embryonic transfer). The difficulty lies mainly in its complex ethical and legal aspects. It is known, for example, that disputes in cases of divorce or death of any of the couple members have led to lengthy legal proceedings, among other things, due to the absence of adequate laws (Cohen \& Adashi, 2016). Some countries restrict or prohibit ED practices, such as Brazil, Denmark, Israel, Japan, Norway, Sweden, Switzerland, Taiwan, and Turkey. In other nations, ED is possible under various conditions, such as in Germany, Australia, Austria, Canada, Spain, U.S., Finland, France, Italy, New Zealand, and the United Kingdom. The donation practice form also varies substantially, from anonymous, which has historically been the most common form of donation, and is allowed in Bulgaria, Denmark, Spain, Greece, India, Portugal, the Czech Republic, and South Africa; and allowed with varying degrees of open donation. On the other hand, Canada, Norway, New Zealand, the Netherlands, the United Kingdom, Sweden, and some states of Australia allow donations in the context of donor identity registration, where those conceived may access a donation program to know their genetic information (Goedeke et al., 2015).

The issue of infertility and ARTs seems to be, at first sight, far from the field of public health and collective health, and nothing could be farther from the truth in this case. On the contrary, some issues show techno-scientific tendencies both in their practice and in reflections from different disciplines. They are part of the contemporary science and technology agenda, and from the bioethical and political viewpoint, a challenge concerning equity and justice.

The impossibility of having children has traditionally been seen as a private issue (Fidler \& Bernstein, 1999). However, public health can contribute significantly by increasing knowledge about infertility, generating healthcare policies for the reasonable prevention of this condition, promoting access to medical care that could include ARTs, and, if doing so, requiring specific regulations. This is even reflected in the specialized academic publications, where a low representation of the issue of infertility is evident even in health journals that focus on women (Place et al., 2018).

Two arguments usually emerge when addressing the issue of infertility in less developed countries: overpopulation, and the limited resources destined for health care (which they suppose, could not prioritize the issue of infertility, associating it to ART costs; Ombelet \& Goossens, 2017). One should not overlook that it has long been known that infertility affects globally much less developed countries than developed countries. While globally estimated at $10 \%$ of the world's population, $80 \%$ of infertility is found in less developed countries (Álvarez-Díaz, 2011). Also, the psychological, social, and economic consequences are worse for infertile men and women in these countries (Rouchou, 2013).

At first, talking about infertility in less developed countries is indeed a huge challenge (Asemota \& Klatsky, 2015). However, no one reasonably proposes that ARTs be provided for the entire population. A first approach, of totally health-related inspiration, is the prevention and timely diagnosis of conditions that generate infertility (Macaluso et al., 2010). For instance, sexually transmitted infections are among the leading causes of infertility, especially in women (Tsevat et al., 2017), but also in men (Gimenes et al., 2014). This is because if the healthcare system does not work properly, these infections may not be diagnosed on time, or are misdiagnosed, or it may be that they are diagnosed on time and correctly, but an erroneous, suboptimal treatment is indicated due to a shortage of system resources, or simply the population does not have the means to pay for the appropriate treatment. 
Finally, there is another high-relevance issue: globalization has reached the field of medical care. Not all countries have the same resources, and within them, not the entire population has the same economic possibilities. Virtually all Latin American countries have medical services that provide ARTs (as already stated, they are mostly private). This causes the emergence of an increasingly studied event: the so-called "medical tourism" (Álvarez-Díaz, 2012), which in this field is called "reproductive tourism" (although it is also called "cross-border reproductive care"). This is the reality throughout Latin America, and was evidenced by discarding several questionnaires precisely because of this type of population. It is also an urgent call to bioethical and legal regulations for this event in all countries, since not doing so attaches risks to public health, problems for international adoptions, and possibility human, tissue, and cell trafficking (Shalev et al., 2016). The issue of the possible improper marketing and cell trafficking has already been raised for ART, concerning oocytes in general (Neri et al., 2016), or the investigation of techniques such as mitochondrial replacement (Dickenson, 2013). As far as embryos are concerned, the possibility of generating markets from the perspective of stem cells has already been raised (Kahn, 2001), and it has already been proposed as a possibility for Latin America in the field of ART for clinical purposes (Álvarez-Díaz, 2005).

This type of research can provide data to analyze from the perspectives of public healthcare and collective healthcare, not only the issue in the health-disease-care process, but also the way to address them, generating reflections and arguments that support the construction of public policies in general, and healthcare policies in particular. If the issue of infertility and ARTs is viewed from the perspective of human rights, the purely individualistic vision can be changed, since respecting sexual and reproductive rights means respecting human rights.

\section{ACKNOWLEDGMENTS}

The author is solely responsible for the interpretation of the results. The author would like to thank Maria Teresa Urbina for her invaluable help and support.

\section{Support}

During the study, the researcher received a scholarship from the National Council of Science and Technology (Consejo Nacional de Ciencia y Tecnología, CONACYT, Mexico) to conduct doctoral studies at the Complutense University of Madrid. The research project won the Manuel Velasco Suárez Award for Excellence in Bioethics 2007 (PAHEF-PA$\mathrm{HO} / \mathrm{WHO}$ ). The first version of this document received the Mark S. Ehrenreich Prize in Healthcare Ethics Research 2014, through the International Association of Bioethics, and The Pacific Center for Healthcare Policy and Ethics at the University of Southern California.

\section{CONFLICT OF INTEREST}

The author declares no conflict of interest.

\section{Corresponding author:}

Jorge Alberto Álvarez-Díaz

Departamento de Atención a la Salud

Universidad Autónoma Metropolitana

Unidad Xochimilco

México.

E-mail: bioetica_reproductiva@hotmail.com; jalvarez@ correo.xoc.uam.mx

\section{REFERENCES}

Álvarez-Díaz JA. Tipos de ansiedad de las parejas tratadas con fertilización asistida frente a la donación hipotética de embriones en el Hospital Clínico de la Universidad de Chile. Ginecol Obstet Mex. 2005;73:163-72.

Álvarez-Díaz JA. Bioética, infertilidad y técnicas de reproducción humana asistida: De la medicina clínica a la medicina social. Salud Problema. 2011;5:8-22.

Álvarez-Díaz JA. Una mirada crítica al turismo reproductivo. Salud Problema. 2012;6:36-54.

Álvarez-Díaz JA. Social and legal issues related to in vitro fertilization. Perinatol Reprod Hum. 2014;28:79-90.

Asemota OA, Klatsky P. Access to infertility care in the developing world: the family promotion gap. Semin Reprod Med. 2015;33:17-22. PMID: 25565507 DOI: 10.1055/s0034-1395274

Bangsbøll S, Pinborg A, Yding Andersen C, Nyboe Andersen A. Patients' attitudes towards donation of surplus cryopreserved embryos for treatment or research. Hum Reprod. 2004;19:2415-9. PMID: 15310730 DOI: 10.1093/ humrep/deh441

Cámara Nacional de Apelaciones en lo Civil. Capital Federal, Ciudad Autónoma deBuenosAires. Sala I. Rabinovich, Ricardo David s/ medidas precautorias. Sentencia 3 de diciembre de 1999 (cited 2019 Jan 9) Available at: http://www. saij.gob.ar/camara-nacional-apelaciones-civil-nacionalciudad-autonoma-buenos-aires-rabinovich-ricardo-davidmedidas-precautorias-fa99020755-1999-12-03/123456789-557-0209-9ots-eupmocsollaf

Cohen IG, Adashi EY. Embryo disposition disputes: controversies and case law. Hastings Cent Rep. 2016;46:13-9. PMID: 27417864 DOI: 10.1002/hast.600

Dayal MB. Indications for egg and embryo donation. In: Sauer MV, ed. Principles of oocyte and embryo donation. 2nd ed. London: Springer; 2013. p. 19-22.

De Wert G, Dondorp W, Shenfield F, Barri P, Devroey P, Diedrich K, Tarlatzis B, Provoost V, Pennings G. ESHRE Task Force on Ethics and Law 23: medically assisted reproduction in singles, lesbian and gay couples, and transsexual people. Hum Reprod. 2014;29:1859-65. PMID: 25052011 DOI: 10.1093/humrep/deu183

Deniz SG, Hughes EG, Neal MS, Faghih M, Amin S, Karnis MF. Are health care providers adequately educating couples for embryo disposition decisions? Fertil Steril. 2016;105:684-9. PMID: 26690006 DOI: 10.1016/j. fertnstert.2015.11.025

Dickenson DL. The commercialization of human eggs in mitochondrial replacement research. New Bioeth. 2013;19:18-29. PMID: 24707594 DOI: $10.1179 / 2050287713 Z .00000000018$

ESHRE Task Force on Ethics and Law. III. Gamete and embryo donation. Hum Reprod. 2002;17:1407-8. PMID: 11980773 DOI: 10.1093/humrep/17.5.1407 
Ethics Committee of American Society for Reproductive Medicine. Access to fertility treatment by gays, lesbians, and unmarried persons: a committee opinion. Fertil Steril. 2013;100:1524-7. PMID: 24094420 DOI: 10.1016/j. fertnstert.2013.08.042

Ethics Committee of the American Society for Reproductive Medicine. Defining embryo donation: an Ethics Committee opinion. Fertil Steril. 2016a;106:56-8. PMID: 27001380 DOI: $10.1016 /$ j.fertnstert.2016.03.017

Ethics Committee of the American Society for Reproductive Medicine. Oocyte or embryo donation to women of advanced reproductive age: an Ethics Committee opinion. Fertil Steril. 2016b;106:e3-e7. PMID: 27450186 DOI: 10.1016/j.fertnstert.2016.07.002

Ethics Committee of the American Society for Reproductive Medicine. Informing offspring of their conception by gamete or embryo donation: an Ethics Committee opinion. Fertil Steril. 2018;109:601-5. PMID: 29605404 DOI: 10.1016/j. fertnstert.2018.01.001

Fidler AT, Bernstein J. Infertility: from a personal to a public health problem. Public Health Rep. 1999;114:494511. PMID: 10670617 DOI: $10.1093 / p h r / 114.6 .494$

Finger R, Sommerfelt C, Freeman M, Wilson CK, Wade A, Daly D. A cost-effectiveness comparison of embryo donation with oocyte donation. Fertil Steril. 2010;93:379-81. PMID: 19406398 DOI: $10.1016 /$ j.fertnstert.2009.03.019

Gilman L, Freivalds S. How to realize the joy of adopting a child. Money. 1997;26:160-74.

Gimenes F, Souza RP, Bento JC, Teixeira JJ, Maria-Engler SS, Bonini MG, Consolaro ME. Male infertility: a public health issue caused by sexually transmitted pathogens. Nat Rev Urol. 2014;11:672-87. PMID: 25330794 DOI: 10.1038/nrurol.2014.285

Goedeke S, Daniels K, Thorpe M, Du Preez E. Building extended families through embryo donation: the experiences of donors and recipients. Hum Reprod. 2015;30:2340-50. PMID: 26251459 DOI: 10.1093/ humrep/dev189

Goedeke S, Daniels K, Thorpe M. Embryo donation and counselling for the welfare of donors, recipients, their families and children. Hum Reprod. 2016;31:412-8. PMID: 26677957 DOI: $10.1093 /$ humrep/dev304

Goldberg D, Tsafrir A, Srebnik N, Gal M, Margalioth EJ, Mor P, Farkash R, Samueloff A, Eldar-Geva T. How many embryos should be transferred? The relevance of parity and obstetric history. Isr Med Assoc J. 2016;18:313-7.

Inter-American Court of Human Rights (site in the Internet). Artavia Murillo y otros (Fertilización in vitro) Vs. Costa Rica; 2012. Available at: http://www.corteidh.or.cr/ cf/Jurisprudencia2/ficha_tecnica.cfm?nId_Ficha $=235$

Kahn J. Will stem cells create a market for human embryos? J Androl. 2001;22:12. DOI: https://doi. org/10.1002/j.1939-4640.2001.tb02146.x
Krones T, Neuwohner E, Bock K, Manolopoulos K, Tinneberg HR, Richter G. Attitudes of patients, healthcare professionals and ethicists towards embryonic stem cell research and donation of gametes and embryos in Germany. Reprod Biomed Online. 2006;13:607-7. PMID: 17169169 DOI: 10.1016/ S1472-6483(10)60650-5

Liebermann J. Human embryo vitrification. Methods Mol Biol. 2017;1568:141-59. PMID: 28421495 DOI: 10.1007/978-1-4939-6828-2_11

Lucena C, Andersson K, Esteban C, Hyllner J, Lucena E. Obtention of the first Latin American human embryonic stem cell line. Fertil Steril. 2006;86:S510. DOI: 10.1016/j. fertnstert.2006.07.1414

Macaluso M, Wright-Schnapp TJ, Chandra A, Johnson $R$, Satterwhite $C L$, Pulver A, Berman SM, Wang RY, Farr SL, Pollack LA. A public health focus on infertility prevention, detection, and management. Fertil Steril. 2010;93:16.e1-10. PMID: 18992879 DOI: 10.1016/j. fertnstert.2008.09.046

MacArthur T, Bachmann G, Ayers C. Menopausal women requesting egg/embryo donation: examining health screening guidelines for assisted reproductive technology. Menopause. 2016;23:799-802. PMID: 27187010 DOI: 10.1097/GME.0000000000000622

Malzac P. Enjeux éthiques autour de la question de I'embryon humain. ADSP. 2011;77:28-30.

Marina S, Marina D, Marina F, Fosas N, Galiana N, Jové I. Sharing motherhood: biological lesbian co-mothers, a new IVF indication. Hum Reprod. 2010;25:938-41. PMID: 20145005 DOI: 10.1093/humrep/deq008

McMahon CA, Gibson FL, Leslie GI, Saunders DM, Porter KA, Tennant CC. Embryo donation for medical research: attitudes and concerns of potential donors. Hum Reprod. 2003;18:8717. PMID: 12660288 DOI: $10.1093 /$ humrep/deg167

Millbank J, Stuhmcke A, Karpin I. Embryo donation and understanding of kinship: the impact of law and policy. Hum Reprod. 2017;32:133-8. PMID: 27927845 DOI: 10.1093/humrep/dew297

Mohler-Kuo M, Zellweger $U$, Duran A, Hohl MK, Gutzwiller F, Mutsch M. Attitudes of couples towards the destination of surplus embryos: results among couples with cryopreserved embryos in Switzerland. Hum Reprod. 2009;24:1930-8. PMID: 19414865 DOI: 10.1093/humrep/dep103

Neri M, Turillazzi E, Pascale N, Riezzo I, Pomara C. Egg production and donation: a new frontier in the global landscape of cross-border reproductive care: ethical concerns. Curr Pharm Biotechnol. 2016;17:316-20. PMID: 26775650 DOI: $10.2174 / 1389201017666160118103418$

Ombelet W, Goossens J. Global reproductive health - Why do we persist in neglecting the undeniable problem of childlessness in resource-poor countries? Facts Views Vis Obgyn. 2017;9:1-3. PMID: 28721178 
Place JM, Litwack I, Vann S. Is infertility as visible as it needs to be given its importance to women's health? Results from a review of women's health journals. Sex Reprod Healthc. 2018;16:80-1. PMID: 29804781 DOI: 10.1016/j.srhc.2018.02.009

Roberts EF. God's laboratory: religious rationalities and modernity in Ecuadorian in vitro fertilization. Cult Med Psychiatry. 2006;30:507-36. PMID: 17120155 DOI: $10.1007 / \mathrm{s} 11013-006-9037-8$

Robertson CD. Generation, gestation, and birth: An important element in the embryo adoption debate. Linacre Q. 2018;85:35-48. PMID: 29970936 DOI: $10.1177 / 0024363918756388$

Rostas S, Droogers A, eds. The popular use of popular religion in Latin America. Amsterdam: CEDLA, Latin American Studies; 1993.

Rouchou B. Consequences of infertility in developing countries. Perspect Public Health. 2013;133:174-9. PMID: 23327901 DOI: $10.1177 / 1757913912472415$

Samorinha C, Pereira M, Machado H, Figueiredo B, Silva S. Factors associated with the donation and non-donation of embryos for research: a systematic review. Hum Reprod Update. 2014;20:641-55. PMID: 24907125 DOI: 10.1093/ humupd/dmu026

Samorinha C, Silva S. A patient-centred approach to embryo donation for research. Isr J Health Policy Res. 2016;5:44. PMID: 27826412 DOI: 10.1186/s13584-0160098-z

Shalev C, Moreno A, Eyal H, Leibel M, Schuz R, Eldar-Geva $T$. Ethics and regulation of inter-country medically assisted reproduction: a call for action. Isr J Health Policy Res. 2016;5:59. PMID: 27980721 DOI: 10.1186/s13584-0160117-0
Sunkara SK, Rittenberg V, Raine-Fenning N, Bhattacharya S, Zamora J, Coomarasamy A. Association between the number of eggs and live birth in IVF treatment: an analysis of 400135 treatment cycles. Hum Reprod. 2011;26:176874. PMID: 21558332 DOI: 10.1093/humrep/der106

Thomson JA, Itskovitz-Eldor J, Shapiro SS, Waknitz MA, Swiergiel JJ, Marshall VS, Jones JM. Embryonic stem cell lines derived from human blastocysts. Science. 1998;282:1145-7. PMID: 9804556 DOI: 10.1126/science.282.5391.1145

Tsevat DG, Wiesenfeld HC, Parks C, Peipert JF. Sexually transmitted diseases and infertility. Am J Obstet Gynecol. 2017;216:1-9. PMID: 28007229 DOI: 10.1016/j. ajog.2016.08.008

Vatican. John Paul II. Evangelium Vitae; 1995. Available at: http://w2.vatican.va/content/john-paul-ii/en/encyclicals/ documents/hf_jp-ii_enc_25031995_evangelium-vitae.html

Wånggren K, Alden J, Bergh T, Skoog Svanberg A. Attitudes towards embryo donation among infertile couples with frozen embryos. Hum Reprod. 2013a;28:2432-9. PMID: 23756704 DOI: $10.1093 /$ humrep/det252

Wånggren K, Prag F, Skoog Svanberg A. Attitudes towards embryo donation in Swedish women and men of reproductive age. Ups J Med Sci. 2013b;118:187-95. PMID: 23786323 DOI: 10.3109/03009734.2013.808294

Wånggren K, Baban M, Svanberg AS. Attitudes toward embryo donation among staff at in vitro fertilization clinics. Acta Obstet Gynecol Scand. 2014;93:765-70. PMID: 24797028 DOI: 10.1111 /aogs. 12407

Zegers F, Salas S, Eds. Bioética, Reproducción y Familia. Santiago: Ediciones UDP; 2014.

Zegers-Hochschild F, Schwarze JE, Crosby JA, Musri C, Urbina MT. Assisted reproductive techniques in Latin America: The Latin American registry, 2016. JBRA Assist Reprod. 2019;23:255-67. PMID: 31364341 DOI: 10.5935/1518-0557.20190037 